\title{
AKTIVITAS ANTIDOTUM AIR KELAPA HIJAU (Cocos nucifera L.) TERHADAP KERACUNAN SIANIDA PADA MENCIT (Mus musculus L.)
}

\author{
Astri Sulistia, Riski Sulistiarini, Muh. Amir M. \\ Laboratorium Penelitian dan Pengembangan Kefarmasian FARMAKA TROPIS Fakultas \\ Farmasi Universitas Mulawarman, Samarinda, Kalimantan Timur \\ Email: astrii.sulistia@gmail.com
}

\begin{abstract}
Cyanide is a toxic compound that can interfere with health and reduce the nutrients bioavailability in the body. These toxins inhibit the body cells to get oxygen so that the most affected are the heart and brain. The aim of this study was to know the effect of green coconut water (Cocos nucifera L.) as an antidote to cyanide poisoning in mice (Mus musculus L.). The method was in vivo antidote activity using potassium cyanide-induced toxic mice. The mice were divided into 3 groups, i.e. negative control, positive control and test group with green coconut water giving 100\% concentration. Each group consisted of 5 mice. Observations of toxic symptoms after the induction of potassium cyanide performed in initial times and and the results are analyzed visually by comparing graphs based on each group of tests during 24 hours of observation. The results showed that the green coconut water with 100\% concentration that given in mice showed the influence of the reduction in toxic symptoms such as abnormal posture. Recovery of toxic effect in the test group by giving green coconut water was no better than the positive control group by giving sodium nitrite and sodium thiosulfate.
\end{abstract}

Keywords: Green coconut water (Cocos nucifera L.), Antidotum, Toxin, Potassium cyanide, Sodium nitrite, Sodium tiosulphate

\begin{abstract}
ABSTRAK
Sianida merupakan senyawa beracun yang dapat mengganggu kesehatan serta mengurangi bioavailabilitas nutrien di dalam tubuh. Racun ini menghambat sel tubuh mendapatkan oksigen sehingga yang paling terkena dampaknya adalah organ jantung dan otak. Penelitian ini bertujuan untuk mengetahui pengaruh pemberian air kelapa hijau (Cocos nucifera L.) sebagai antidotum terhadap keracunan sianida pada mencit (Mus musculus L.). Metode yang digunakan adalah metode secara in vivo dengan menggunakan hewan uji mencit yang diinduksi kalium sianida. Mencit dibagi ke dalam 3 kelompok, yaitu kelompok kontrol negatif, kontrol positif dan kelompok uji dengan pemberian air kelapa hijau konsentrasi $100 \%$. Setiap kelompok terdiri dari 5 ekor mencit. Pengamatan gejala toksik yang muncul setelah induksi kalium sianida dilakukan pada menit tertentu dan hasil yang didapat dianalisis secara visual berdasarkan berdasarkan grafik perbandingan pada masing-masing kelompok pengujian selama 24 jam pengamatan. Hasil menunjukkan bahwa air kelapa hijau dengan konsentrasi $100 \%$ yang diberikan pada mencit menunjukkan adanya pengaruh terhadap penurunan gejala toksik berupa sikap tubuh yang tidak normal. Efek pemulihan pada kelompok uji dengan pemberian air kelapa hijau tidak lebih baik dari kelompok kontrol positif dengan pemberian natrium nitrit dan natrium tiosulfat.
\end{abstract}


Kata kunci: Air kelapa hijau (Cocos nucifera L.), Antidotum, Racun, Sianida, Natrium nitrit, Natrium tiosulfat

\section{PENDAHULUAN}

Sianida adalah senyawa yang mengandung ion sianida $\left(\mathrm{CN}^{-}\right)$, yang terdiri dari atom karbon (C) yang berikatan rangkap tiga pada atom nitrogen $(\mathrm{N})$. Sianida atau senyawa sianogenik dapat ditemui dalam banyak makanan. Senyawa sianida terbentuk secara alami sebagai bagian dari gula atau senyawa alami lainnya, termasuk almond, kecambah millet, kacang lima, kedelai, bayam, rebung, sorgum dan singkong (Anonim, 2010).

Sianida dapat masuk ke dalam tubuh melalui inhalasi (menghirup), ingesti (menelan) atau absorpsi (penyerapan langsung). Tingkat keparahan toksisitas sianida tergantung pada jenis sianida yang terpapar, rute masuk, dosis dan kecepatan onset gejala (Varone, dkk., 2006).Walaupun sianida dapat mengikat dan menginaktifkan beberapa enzim, tetapi yang mengakibatkan timbulnya kematian atau anoksia histotoksik adalah karena sianida mengikat bagian aktif dari enzim sitokrom oksidase sehingga akan mengakibatkan terhentinya metabolisme sel secara aerobik sebagai akibatnya hanya dalam waktu beberapa menit akan mengganggu transmisi neuronal. Gejala yang ditimbulkan oleh zat kimia sianida bermacam-macam; mulai dari rasa nyeri pada kepala, mual, muntah, sesak nafas, dada berdebar, selalu berkeringat hingga korban tidak sadar dan mengalami kematian. Penatalaksanaan dari korban keracunan ini harus cepat, karena prognosis dari terapi yang diberikan juga sangat tergantung dari lamanya kontak dengan zat toksik tersebut (Baskin dan Thomas, 1997).

Penggunaan tumbuhan obat kerap digunakan oleh orang banyak karena relatif memiliki efek samping yang kecil dan lebih murah bila dibandingkan dengan obat-obatan sintesis. Kelapa (Cocos nucifera L.) merupakan salah satu tumbuhan yang umumnya terdapat di daerah tropis, khususnya Indonesia. Secara empiris, air kelapa hijau seringkali digunakan dalam penanganan kasus keracunan akut di masyarakat. Air kelapa hijau, yang secara teknis merupakan cairan endosperma, dibentuk dalam jumlah sedikit pada bulan ketiga perkembangan biji dan mencapai jumlah tertinggi pada bulan kedelapan dan menurun setelah biji telah matang (Duarte et al, 2002). Dalam air kelapa terkandung zat gizi makro berupa karbohidrat, lemak dan protein serta zat gizi mikro berupa vitamin dan mineral. Vitamin yang terkandung dalam air kelapa yaitu vitamin $B\left(B_{1}, B_{2}, B_{3}, B_{5}, B_{7}\right.$ dan $B_{9}$ ) dan vitamin $C$ serta Nitrogen $(N)$, Fosfor (P), Kalium (K), Kalsium (Ca) dan Magnesium (Mg) yang kadarnya menurun selama maturitas (Farapti dan Savitri, 2014). Berdasarkan data kandungan zat gizi makro dan mikro dalam air kelapa hijau dan penjelasan mengenai bahaya sianida bagi manusia maka diperlukan penelitian toksikologi akut mengenai seberapa besar konsentrasi air kelapa hijau yang efektif untuk mengatasi keracunan sianida.

\section{METODE PENELITIAN}

\section{Bahan}

Bahan yang digunakan adalah air kelapa hijau, aquades, etanol $70 \%$, kalium sianida $(\mathrm{KCN})$, mencit, natrium nitrit dan natrium tiosulfat.

\begin{abstract}
Alat
Alat yang digunakan antara lain timbangan analitik Precisa $^{\circledR}$ XB 220 A, botol semprot, cawan porselen, batang pengaduk, corong kaca, labu ukur, sendok tanduk dan spatula, sonde oral,
\end{abstract}


spuit, kandang mencit serta alat-alat gelas yang mendukung pengujian.

\section{Pengambilan Sampel}

Air kelapa hijau (Cocos nucifera L.) yang digunakan untuk pengujian berasal dari buah kelapa hijau yang diperoleh di Samarinda, Kalimantan Timur. Sampel yang diteliti berasal dari kelapa hijau yang berumur 6-8 tahun dengan produksi air rata-rata $300-500$ $\mathrm{mL}$.

\section{Prosedur Pengujian}

\section{Pengujian Aktivitas Antidotum}

Pada tahap ini, 15 ekor hewan uji dari ketiga kelompok perlakuan dipuasakan selama 8-12 jam namun tetap diberi minum. Selanjutnya semua kelompok hewan uji diberi kalium sianida $(\mathrm{KCN}) \quad 6,375 \mathrm{mg} / \mathrm{kgBB}$ secara oral lalu diberikan perlakuan sesuai kelompoknya masing-masing. Hewan kelompok uji diberi air kelapa hijau dengan konsentrasi $100 \%$, sedangkan kelompok kontrol negatif diberi aquades dan kelompok kontrol positif diberi antidot berupa natrium tiosulfat dan natrium nitrit secara intraperitonial. Kemudian dilakukan pengamatan tiap interval 5 menit yaitu pada menit ke-5, menit ke-10 dan menit ke-15. Jika hewan uji hingga 15 menit pertama pengamatan tidak mengalami kematian maka pengamatan dilanjutkan hingga 1 jam dari waktu pemberian antidot. Pengamatan dilanjutkan hingga 24 jam apabila tidak ditemukan kematian pada 1 jam pengamatan sebelumnya. Kriteria pengamatan gejala toksik pada hewan uji setelah pemberian racun meliputi sikap tubuh yang tidak normal, berupa abduksi (posisi kaki hewan terbuka), ataksia (sempoyongan) dan ketidakmampuan hewan untuk menunjukkan righting reflex serta kematian hewan uji.

\section{HASIL DAN PEMBAHASAN}

\section{Aktivitas Antidotum Air Kelapa Hijau (Cocos nucifera L.) terhadap Keracunan Sianida pada Mencit (Mus musculus L.)}

Pengujian dilakukan dengan mengamati gejala toksik mencit pada masing-masing kelompok setelah pemberian zat uji. Sebanyak 3 kelompok hewan uji diberikan perlakuan yang berbeda setelah pemberian larutan $\mathrm{KCN}$ secara oral. Pada kelompok kontrol negatif, hewan hanya diberikan aquades per oral, sedangkan pada kelompok kontrol positif hewan diberikan kombinasi natrium nitrit dengan dosis $62,46 \mathrm{mg} / \mathrm{kgBB}$ dan natrium tiosulfat dengan dosis 22,96 mg/kgBB (Tintus, 2008). Pemberian natrium tiosulfat ini dilakukan secara intraperitonial sesaat setelah pemberian natrium nitrit. Penggunaan kedua obat tersebut diketahui memiliki efek yang sinergis sebagai antidot terhadap keracunan sianida. Adapun hewan pada kelompok uji diberikan air kelapa hijau dengan konsentrasi $100 \%$.

Kriteria pengamatan gejala toksik pada hewan uji setelah pemberian racun meliputi sikap tubuh yang tidak normal dan kematian. Berikut hasil pengamatan masing-masing gejala toksik pada tiap kelompok.

\section{Sikap Tubuh Tidak Normal}

Penilaian sikap tubuh merupakan parameter untuk melihat terjadinya inkoordinasi alat gerak pada hewan uji. Hasil pengamatan antar kelompok uji berdasarkan parameter ketidaknormalan sikap tubuh ditunjukkan oleh Tabel 1.

Tabel 1 menunjukkan hasil pengamatan antar kelompok uji berdasarkan parameter ketidaknormalan sikap tubuh. Sikap tubuh yang tidak normal pada mencit uji menggambarkan adanya inkoordinasi motorik. Gejala yang menandakan sikap tubuh yang tidak 
normal diantaranya abduksi (posisi kaki hewan terbuka), ataksia (sempoyongan) dan ketidakmampuan hewan untuk menunjukkan reaksi refleks (righting reflex). Pengujian ini digunakan untuk mengetahui fungsi neurologis dan komplikasinya yang sering terjadi pada manusia yang terpapar dosis subletal sianida (Pudjiastuti dan Yun, 2009).

Berdasarkan pengamatan yang dilakukan pada hewan uji berupa mencit, diketahui bahwa pada kelompok kontrol negatif seluruh mencit menunjukkan gejala toksik berupa sikap tubuh yang tidak normal pada menit ke-0 $\left(\mathrm{t}_{1}\right)$ hingga menit ke-15 $\left(\mathrm{t}_{4}\right)$ pengamatan. Terdapat 1 ekor hewan uji yang menunjukkan aktivitas pemulihan gejala toksik pada jam ke-1 ( $\left.\mathrm{t}_{5}\right)$, dimana masih terdapat 4 ekor hewan uji yang memperlihatkan adanya gejala toksik. Pada jam ke-24 ( $\left.\mathrm{t}_{6}\right)$ pengamatan, seluruh hewan uji telah menunjukkan aktivitas pemulihan gejala toksik yaitu sikap tubuh yang telah kembali normal.

Pada kelompok kontrol positif terlihat bahwa seluruh mencit pada kelompok tersebut menunjukkan gejala toksik berupa sikap tubuh yang tidak normal pada pengamatan menit ke- $0\left(\mathrm{t}_{1}\right)$ hingga menit ke-15 $\left(\mathrm{t}_{4}\right)$. Pada pengamatan jam ke-1 $\left(\mathrm{t}_{5}\right)$, seluruh mencit telah menunjukkan aktivitas pemulihan gejala toksik yaitu sikap tubuh yang normal. Waktu pemulihan gejala toksik lebih cepat dibanding kelompok kontrol negatif.

Tabel 1.Hasil Pengamatan Antar Kelompok Uji berdasarkan Parameter Sikap Tubuh: Tidak Normal

\begin{tabular}{clcccccc}
\hline \multirow{2}{*}{ No. Kelompok Uji } & \multicolumn{6}{c}{$\%$ Gejala Toksik (Sikap Tubuh: Tidak Normal) } \\
\cline { 3 - 7 } & & $\mathrm{T}_{1}$ & $\mathrm{~T}_{2}$ & $\mathrm{~T}_{3}$ & $\mathrm{~T}_{4}$ & $\mathrm{~T}_{5}$ & $\mathrm{~T}_{6}$ \\
\cline { 2 - 7 } 1 & Kontrol Negatif & $100 \%$ & $100 \%$ & $100 \%$ & $100 \%$ & $80 \%$ & $0 \%$ \\
2 & Kontrol Positif & $100 \%$ & $100 \%$ & $100 \%$ & $100 \%$ & $0 \%$ & $0 \%$ \\
3 & Air kelapa Hijau & $100 \%$ & $100 \%$ & $100 \%$ & $100 \%$ & $20 \%$ & $0 \%$ \\
& Konsentrasi 100\% & & & & & & \\
\hline
\end{tabular}

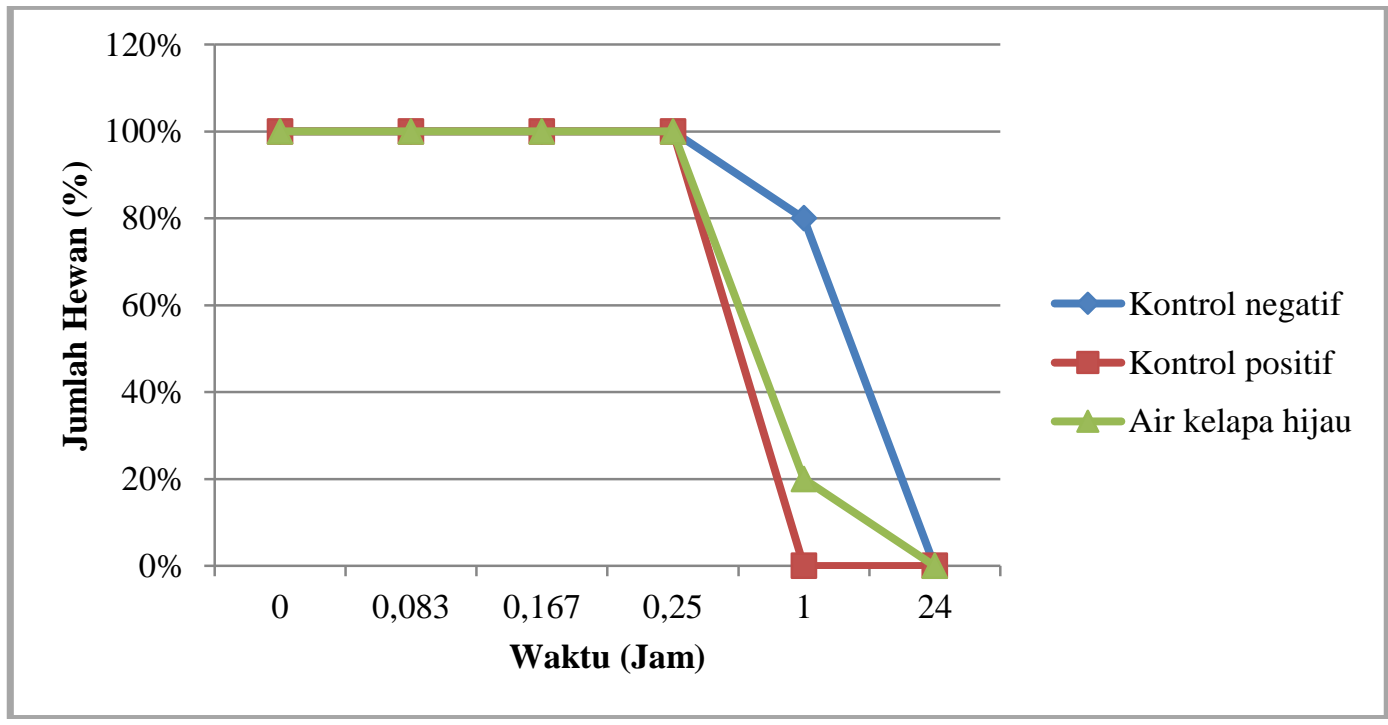

Gambar 1. Grafik Perbandingan Jumlah Hewan (\%) yang menunjukkan Gejala Toksik berupa Sikap Tubuh yang Tidak Normal selama 24 Jam Pengamatan 
Adapun pada kelompok pengujian dengan pemberian air kelapa hijau konsentrasi $100 \%$, terlihat bahwa seluruh hewan uji menunjukkan gejala sikap tubuh yang tidak normal pada menit ke-0 $\left(\mathrm{t}_{1}\right)$ hingga menit ke-15 ( $\left.\mathrm{t}_{4}\right)$ pengamatan. Pada pengamatan jam ke-1 (ts) terlihat bahwa terdapat 4 ekor hewan uji yang telah menunjukkan aktivitas pemulihan gejala toksik yaitu sikap tubuh yang telah kembali normal dan pengamatan jam ke-24 ( $\left.\mathrm{t}_{6}\right)$ menunjukkan bahwa seluruh mencit telah menunjukkan aktivitas berupa sikap tubuh yang telah kembali normal, yaitu tidak menunjukkan gejala abduksi, ataksia maupun righting reflex. Hal tersebut dapat dilihat pada Gambar 1.

Berdasarkan Gambar 1 terlihat perbedaan aktivitas antidotum antara ketiga kelompok pengujian tersebut. Pada pengamatan menit ke- $0\left(t_{1}\right)$ hingga menit ke-15 ( $\left.\mathrm{t}_{4}\right)$, jumlah hewan yang menunjukkan adanya gejala toksik pada ketiga kelompok pengujian adalah $100 \%$, artinya sebanyak 5 hewan uji pada masing-masing kelompok tersebut menunjukkan gejala toksik berupa sikap tubuh yang tidak normal. Pada pengamatan jam ke-1 ( $\left.\mathrm{t}_{5}\right)$, terlihat bahwa jumlah hewan yang menunjukkan adanya gejala toksik pada kelompok kontrol negatif adalah $80 \%$, yang berarti terdapat 4 ekor hewan uji pada kelompok tersebut menunjukkan adanya gejala toksik, sedangkan 1 ekor hewan telah menunjukkan aktivitas antidotum berupa pemulihan gejala toksik yaitu sikap tubuh yang telah kembali normal. Jumlah hewan uji pada kelompok kontrol positif yang menunjukkan gejala toksik adalah $0 \%$, yang artinya tidak terdapat hewan uji yang menunjukkan gejala toksik atau kelima hewan uji telah menunjukkan sikap tubuh yang normal. Adapun jumlah hewan uji pada kelompok pengujian dengan pemberian air kelapa hijau adalah $20 \%$, yang berarti terdapat 1 ekor hewan uji yang menunjukkan adanya gejala toksik berupa sikap tubuh yang tidak normal sedangkan 4 ekor hewan uji yang lain telah menunjukkan adanya aktivitas antidotum berupa penormalan sikap tubuh yaitu tidak menunjukkan gejala abduksi, ataksia maupun righting reflex. Pada pengamatan jam ke-24 $\left(\mathrm{t}_{6}\right)$, jumlah hewan uji pada seluruh kelompok yang menunjukkan gejala toksik adalah $0 \%$, atau tidak ada hewan yang menunjukkan gejala sikap tubuh yang tidak normal. Berdasarkan hasil uji tersebut, maka dapat disimpulkan bahwa pemberian air kelapa hijau dengan konsentrasi 100\% memberikan pengaruh sebagai antidot pada keracunan sianida, namun tidak lebih baik dari kelompok kontrol positif dengan pemberian natrium nitrit dan natrium tiosulfat.

Selain pengamatan gejala toksik berupa sikap tubuh yang tidak normal, dilakukan pula pengamatan jumlah kematian mencit pada masing-masing kelompok setelah pemberian senyawa uji. Setelah dilakukan pengamatan pada menit ke-0 $\left(\mathrm{t}_{1}\right)$, menit ke-5 $\left(\mathrm{t}_{2}\right)$, menit ke$10\left(\mathrm{t}_{3}\right)$, menit ke-15 $\left(\mathrm{t}_{4}\right)$, jam ke-1 $\left(\mathrm{t}_{5}\right)$ dan jam ke-24 $\left(\mathrm{t}_{6}\right)$, tidak ditemukan adanya kematian pada mencit pada seluruh kelompok uji.

\section{Kandungan Mineral Air Kelapa Hijau (Cocos nucifera L.) dalam Aktivitasnya sebagai Antidotum}

Konsentrasi yang tinggi dari $\mathrm{Na}$ dan kadar yang cukup dari $\mathrm{K}$ dalam air kelapa menjadikannya elektrolit yang cocok dan dapat digunakan dalam perlindungan terhadap dehidrasi dan pemeliharaan tekanan osmotik dalam tubuh. Penggunaan air kelapa pada pasien dehidrasi, sebagai minuman olahraga dan pengobatan sejumlah penyakit seperti penyakit jantung kongestif, diabetes dan penyakit menular telah banyak dilaporkan. Na juga berperan dalam iritabilitas normal pada otot dan permeabilitas sel, sementara kalium merupakan kation utama cairan intraseluler yang terlibat dalam sintesis protein (Waziri et al., 2013). Kekurangan 
$\mathrm{Na}$ akan menyebabkan tubuh kekurangan cairan yang apabila terus berlangsung, air akan ditarik ke dalam sel dan apabila volume plasma tidak dapat dipertahankan terjadilah kegagalan sirkulasi. sedangkan konsentrasi kalium yang terlalu tinggi atau terlalu rendah dapat menyebabkan timbulnya masalah serius, seperti irama jantung yang abnormal (Arsa, 2011). Di sisi lain, Ca juga merupakan komponen yang sangat diperlukan sebagai penyusun struktur tubuh, menjaga kekerasan dan kekuatan tulang dan gigi dengan adanya elemen mineral ini. Mineral lain yang juga ditemukan di dalam air kelapa termasuk $\mathrm{Mg}$, Fe dan $\mathrm{Zn}$. Mg diperlukan untuk membentuk ATP dan dalam pembentukan tulang. Fe, yang merupakan penyusun hemoglobin, mioglobin dan sejumlah enzim, merupakan nutrisi yang sangat dibutuhkan manusia. Zn, penyusun dari enzim yang terlibat dalam jalur metabolisme utama, merupakan elemen yang penting bagi tanaman, hewan dan manusia (Waziri et al., 2013).

\section{KESIMPULAN}

Air kelapa hijau dengan konsentrasi $100 \%$ yang diberikan pada mencit menunjukkan adanya pengaruh terhadap penurunan gejala toksik berupa sikap tubuh yang tidak normal serta pemberian natrium nitrit dan natrium tiosulfat pada kelompok kontrol positif memberikan pengaruh yang lebih baik sebagai antidot terhadap keracunan sianida dibandingkan pemberian air kelapa hijau dengan konsentrasi 100\%

\section{DAFTAR PUSTAKA}

1. Anonim. 2010. Toxicological Review of Hydrogen Cyanide and Cyanide Salts. U.S. Environmental Protection Agency. Washington DC. Hal: 3-17

2. Arsa, Made. 2011. Kandungan Natrium dan Kalium Larutan Isotonik Alami Air Kelapa (Cocos nucifera L.) Varietas Eburnia, Viridis dan Hibrida. Universitas Udayana. Denpasar

3. Baskin, Steven I. Dan Thomas G. Brewer. 1997. Medical Aspects of Chemical and Biological Warfare. Department of the Army. United States of America

4. Duarte, A.C.P., Coelho, M.A.Z., Leite, S.G.F. 2002. Identification of Peroxidase and Tyrosinase in Green Coconut Water

5. Farapti dan Savitri Sayogo. 2014. Air Kelapa Muda-Pengaruhnya terhadap Tekanan Darah. Jurnal CDK-23 Vol. 41 No. 12. Hal: 896-900

6. Tintus, Libertus H. 2008. Dosis Efektif Kombinasi Natrium Tiosulfat dan Natrium Nitrit sebagai Antidotum Keracunan Sianida Akut pada Mencit Jantan Galur Swiss. Universitas Sanata Dharma. Yogyakarta

7. Varone, Curtis., Thomas N. Warren., Kevin Jutras., Joseph Molis., Joseph Dorsey. 2006. Report of Investigation Committee into the Cyanide Poisonings of Providence Firefighters. Hal: 7-17

8. Waziri, Maimuna., Abdulrahman A. Audu dan Fanika Suleiman. 2013. Analysis of Some Mineral Elements in Major Coconut Cultivars in Nigeria. Journal of Natural Sciences Research Vol. 3 No. 8. Hal: 7-11 